\title{
ASSESSMENT OF INFINITE-AGE BONES FROM THE UPPER THAMES VALLEY, UK, AS ${ }^{14} \mathrm{C}$ BACKGROUND STANDARDS
}

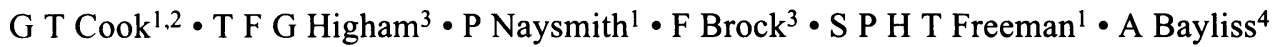

\begin{abstract}
It is becoming increasingly clear that in order to generate accurate radiocarbon dates for bone collagen samples it is important to determine a sample-specific background correction to account for the greater complexity and higher number of steps in the pretreatment chemistry of this material. To provide suitable samples for the ${ }^{14} \mathrm{C}$ community, 7 bone samples were obtained from contexts within British gravel quarries, which according to other dating techniques or stratigraphic information, should be of infinite age with respect to ${ }^{14} \mathrm{C}$. The bones were analyzed at the Oxford Radiocarbon Accelerator Unit (ORAU) and the Scottish Universities Environmental Research Centre (SUERC) to determine their suitability. In this paper, we show that 6 of the samples were indistinguishable from background. Both institutions measured finite ages for sample 387 from Oxey Mead that were statistically indistinguishable. Further work is required to establish whether this is because the bone was intrusive and of a younger age than expected or whether it is contaminated either postdepositionally or in the laboratory. We favor the former explanation because (1) the 2 chemistry laboratories use very different pretreatment schemes, (2) collagen yields were high, and (3) the laboratories produced ages that are in good agreement. The 6 "greater than" age samples will be made available to ${ }^{14} \mathrm{C}$ laboratories to be used as background standards.
\end{abstract}

\section{INTRODUCTION}

Radiocarbon dating of bone or antler can be challenging. It is a relatively difficult material to pretreat effectively and many different methods have been reported, with varying degrees of success, since the widely adopted method proposed by Longin (1971). Chemical pretreatment of bone is designed to isolate the protein fraction from the hydroxyapatite as well as from contaminants present from the postdepositional environment, while simultaneously trying to avoid adding laboratory contaminants. It is a balance between the two, because the more complex chemistry that is applied the more likely it is that additional contamination is added to the activity of the sample that is to be dated.

Much recent literature concerning methods of dating bone focuses on chemical pretreatment methodology: the use of ultrafiltration in purifying the collagen extract (Brown et al. 1988; Bronk Ramsey et al. 2004; Higham et al. 2006; but see Hüls et al. 2007, 2009; Brock et al. 2007); the application of ninhydrin derivatization of bone collagen (Nelson 1991; Tisnérat-Laborde et al. 2003); and the dating of single amino acids (Stafford et al. 1991; McCullagh et al. 2010). Another area of interest concerns the parameters that are useful in diagnosing whether or not bone samples can be considered suitable for ${ }^{14} \mathrm{C}$ dating (e.g. percentage collagen in bone, percent carbon, percent nitrogen, $\mathrm{C} / \mathrm{N}$ ratio, etc.) and the methods used in evaluating and removing possible contaminants (van Klinken 1999; D'Elia et al. 2007; Yuan et al. 2007).

One area that has been neglected by comparison is that of background correction. Multiple steps are involved in the pretreatment processes for bone and so the background associated with this material has been found to be somewhat greater than that typically associated with other sample types (e.g. Tisnérat-Laborde et al. 2003; Wood et al. 2010). Therefore, it is very important, particularly when

${ }^{1}$ Scottish Universities Environmental Research Centre, Scottish Enterprise Technology Park, East Kilbride G75 0QF, United Kingdom.

${ }^{2}$ Corresponding author. Email: Gordon.Cook@glasgow.ac.uk.

${ }^{3}$ Oxford Radiocarbon Accelerator Unit, Research Laboratory for Archaeology and the History of Art, University of Oxford, Oxford, United Kingdom.

${ }^{4}$ English Heritage, 1 Waterhouse Square, 138-142 Holborn, London EC1N 2ST, United Kingdom.

C 2012 by the Arizona Board of Regents on behalf of the University of Arizona Proceedings of the 6th International Radiocarbon and Archaeology Symposium, edited by E Boaretto and N R Rebollo Franco RADIOCARBON, Vol 54, Nr 3-4, 2012, p 845-853 
measuring bones older than Holocene age that bone samples of infinite age with respect to ${ }^{14} \mathrm{C}$ are prepared and measured in association with unknown-age material. These bone standards can be used to provide an estimate of the background activity necessary for correcting the ${ }^{14} \mathrm{C}$ activities of the unknowns being dated. The availability of this type of material is important if progress is to be made in determining why background activities from bone are higher than those for other sample types. However, samples that are of sufficient mass with good levels of collagen preservation and whose ages are sufficiently well characterized to be useful as a standard are relatively rare. It is very important to obtain suitable bones that are uncontaminated with environmentally derived carbon as this enables the laboratory to more accurately quantify the chemistry background and eliminate the possibility of overcorrecting unknown bone samples using a chemistry background that incorporates both laboratory background and environmental contaminants.

\section{OBJECTIVES}

This project forms part of the quality assurance procedures commissioned by English Heritage alongside the ${ }^{14} \mathrm{C}$ dating undertaken in support of its wider archaeological research program. Bone and antler samples are a critical part of this research, providing more than a quarter of all the samples submitted for dating by English Heritage over the past $50 \mathrm{yr}$.

Over the past $20 \mathrm{yr}$, as ${ }^{14} \mathrm{C}$ dating of this material has become more reliable (Hedges and van Klinken 1992; Jacobi et al. 2006) and Bayesian chronological modeling has been routinely adopted for the interpretation of archaeological chronologies (Bayliss and Bronk Ramsey 2004; Bayliss 2009), the ongoing proportion of bone and antler samples dated has increased substantially. This is because of the potential for articulated or articulating bone groups to provide samples that are demonstrably not residual. These types of samples provide ${ }^{14} \mathrm{C}$ ages that can be combined with stratigraphic sequences in Bayesian models to produce dating that can be precise to within a few decades (e.g. Bayliss and Whittle 2007). If the dating suggested by chronological modeling of this type is to be considered reliable, then it is essential that the ${ }^{14} \mathrm{C}$ determinations incorporated into the models are accurate to within the precision quoted (Bayliss et al. 2007: Figures 21-24).

For bone and antler samples of Holocene age, a separate bone blank is becoming increasingly necessary, although given the difficulty of obtaining suitable material that is reliably of this antiquity the use of an error multiplier to account for the difference in background may be a viable alternative. For example, for the wheel of accelerator mass spectrometry (AMS) samples within which the bone and other sample types in this study were measured at SUERC, the average fraction modern (Fm) value for the organic background (an interglacial wood sample) was $0.0015 \pm 0.0003$ and the bone blank was $0.0034 \pm 0.0007$. For a sample that is 1 half-life old, the age difference using the 2 different background values would amount to an offset of $\sim 30 \mathrm{yr}$; for a sample which is 2 half-lives old, the age difference is about $60 \mathrm{yr}$, increasing to $\sim 250 \mathrm{yr}$ for a sample that is 4 half-lives old, and approximately $1160 \mathrm{yr}$ for a sample $\sim 6$ half-lives in age. A separate bone background is therefore essential for accurately dating samples of Pleistocene age, and is also a necessity for high-precision measurements and for dates that are to be included in Bayesian chronological models in the Holocene, where biases of this magnitude become significant (cf. Bayliss et al. 2007: Figure 23). Therefore, the objectives of this project were to:

1. Source large herbivore bones known independently to be older than $60,000 \mathrm{yr}$;

2. Determine whether their collagen contents were sufficiently well preserved for ${ }^{14} \mathrm{C}$ dating;

3. Confirm a background age for the samples;

4. Explore possible contamination of the bone and the suitability of the samples for use as a laboratory background standard. 


\section{THE SAMPLES}

Seven bones were kindly provided by Dr Katharine Scott (St Cross College, Oxford) from sites in the Upper Thames Valley, which had been investigated in advance of gravel extraction over the past 20 yr. Sample and site details are provided in Table 1.

Table 1 Details of the bone samples.

\begin{tabular}{|c|c|c|c|c|}
\hline Site & $\begin{array}{l}\text { Sample } \\
\text { reference }\end{array}$ & Identification & $\begin{array}{l}\text { Weight } \\
(\mathrm{g})\end{array}$ & $\begin{array}{l}\text { Expected } \\
\text { age }^{\mathrm{a}}\end{array}$ \\
\hline Latton Quarry & LQL4 & $\begin{array}{l}\text { Mammuthus cf. trongontherii, } \\
\text { ?femur }\end{array}$ & 2425 & MIS 7 \\
\hline Latton Quarry & LQH12 & $\begin{array}{l}\text { Mammuthus } \text { cf. trongontherii, } \\
\text { right humerus }\end{array}$ & 4525 & MIS 7 \\
\hline Latton Quarry & LQL15 & Equus ferus, right tibia & 750 & MIS 7 \\
\hline Oxey Mead & 369 & Bison, right radius & 750 & MIS 5a \\
\hline Oxey Mead & 387 & Bison, right tibia & 675 & MIS 5a \\
\hline Yarnton & Yarnton & Bovinae, right femur & 1250 & MIS 5a \\
\hline Thrupp: Tuckwell's Pit & RDTW $01<59>$ & Bison, right tibia & 900 & MIS 5a \\
\hline
\end{tabular}

${ }^{a}$ MIS 7 = Marine Isotope Stage 7; MIS 5 = Marine Isotope Stage 5a.

The site at Latton Quarry, Gloucestershire/Wiltshire (UK), lies close to the River Churn, a northbank tributary of the River Thames. The deposits are mainly of medium to coarse limestone gravels, with minor fine-grained facies. They are of fluvial origin. These gravels (Association A) contain faunal material indicating temperate conditions, including a distinctive small form of mammoth (Mammuthus cf. trogontherii). This, together with a U-series age estimate of $>147.4 \pm 20 \mathrm{kyr}$, suggests that these deposits may correlate with Marine Isotope Stage 7 (MIS 7) (Scott and Buckingham 2001; Lewis et al. 2006).

The remaining samples derive from faunal assemblages attributed to Marine Isotope Stage 5a (MIS 5a) from gravel quarries in Oxfordshire, UK. The ARC (later Hanson Aggregates) gravel pit between Yarnton and Cassington produced bones from 2 deposits of this date at Oxey Mead and Yarnton (K Scott, personal communication). The Pleistocene river channel at Tuckwell's pit, Thrupp, provided another sample from a deposit containing bison, reindeer, wolf, and bear remains. These sediments have been dated by optically stimulated luminescence (OSL) to between 90 and 70 kyr (Eeles 2009).

\section{LABORATORY METHODS}

All 7 samples were processed and measured at both the Oxford Radiocarbon Accelerator Unit (ORAU) and the Scottish Universities Environmental Research Centre (SUERC). At Oxford, each of the bones was shot-blasted to clean the surface and sampled using an NSK Electer GX drill with a tungsten carbide drill bit. Between 500 and $1000 \mathrm{mg}$ of bone were taken for analysis. Bone collagen was extracted using the manual Oxford method (Higham et al. 2006; Brock et al. 2010). Bone powder was decalcified with $0.5 \mathrm{M} \mathrm{HCl}$, an $0.1 \mathrm{M} \mathrm{NaOH}$ wash was then applied, followed by reacidification using $0.5 \mathrm{M} \mathrm{HCl}$. Ultrapure Milli- $\mathrm{Q}^{\mathrm{TM}}$ water was used to rinse the sample between each stage. Gelatinization of the collagen was undertaken using weakly acidic, $\mathrm{pH} 3$ water at $75^{\circ} \mathrm{C}$ in an incubator for $20 \mathrm{hr}$. The gelatin solution was filtered using an Ezee-filter ${ }^{\mathrm{TM}}$, and any solids discarded. A Vivaspin ${ }^{\mathrm{TM}}$ 30-kD MWCO ultrafilter was used to ultrafilter the gelatin solution (Bronk Ramsey et al. 2004; Higham et al. 2006). The $>30-\mathrm{kD}$ fraction was freeze-dried in preparation for 
dating, while the $<30-\mathrm{kD}$ fraction was discarded. Approximately $5 \mathrm{mg}$ of ultrafiltered gelatin were weighed into precleaned tin capsules and combusted using a Carlo Erba elemental analyzer interfaced with an isotope ratio mass spectrometer (Sercon 20/20). This operates in a continuous-flow mode with a He carrier gas. $\delta^{13} \mathrm{C}$ values in this paper are reported with reference to VPDB, $\delta^{15} \mathrm{~N}$ values with respect to AIR. Samples were graphitized from $\mathrm{CO}_{2}$ using an iron catalyst in an excess hydrogen atmosphere (Dee and Bronk Ramsey 2000). The Oxford spectrometer is described by Bronk Ramsey et al. (2004). ${ }^{14} \mathrm{C}$ dates are based on standard measurements at 3 separate stages of the dating process. First, an AMS blank correction is applied to all samples measured on the accelerator based on measurements of gas derived from pure anthracite. This corrects for background picked up at the graphitization and AMS measurement stage. Second, a combustion correction is applied based on the measurement of alanine standards that are analyzed alongside every group of samples combusted in the EA-IRMS. This correction averages $0.0007 \pm 0.0010 \mathrm{mg}$ C. Finally, for bone, a sample-specific chemistry background correction is applied, based on the measurement of tens of beyond-background bone samples from the start of pretreatment chemistry to the final AMS measurement. This has been described in detail by Wood et al. (2010). The correction is derived from a regression model based on inverse collagen yield plotted against $\mathrm{Fm} C$. This effectively sets a maximum background age of 49,900 BP for bone determinations and allows a correction to be applied that is collagen size dependent down to $5 \mathrm{mg}$ collagen weight. All results are expressed as conventional ${ }^{14} \mathrm{C}$ ages BP after Stuiver and Polach (1977).

At SUERC, whole fragments of bone (several mm diameter) were first cleaned by abrading the surface with a Dremmel ${ }^{\circledR}$ tool fitted with a small buff. The fragments were then placed in cold molar $\mathrm{HCl}$ for approximately 4 days to effect demineralization, which was assessed visually. The acid solution was then decanted and the collagen washed in reverse osmosis water and then placed in further reverse osmosis water. Where necessary, a small amount of $0.5 \mathrm{M} \mathrm{HCl}$ was added to adjust the $\mathrm{pH}$ of the solution to 3 . The solution was then heated gently $\left(\sim 80^{\circ} \mathrm{C}\right)$ to dissolve/gelatinize the collagen and then cooled, filtered through Whatman GF/A glass fiber paper, and freeze-dried. Subsamples of 15-20 mg were combusted in sealed quartz tubes containing copper oxide and silver foil according to the method of Vandeputte et al. (1996). All $\mathrm{CO}_{2}$ samples were extracted under vacuum, cryogenically purified, and prepared as graphite targets according to the method of Slota et al. (1987). The ${ }^{14} \mathrm{C} /{ }^{13} \mathrm{C}$ ratios of the graphitized samples were measured on the SUERC single-stage accelerator mass spectrometer (Freeman et al. 2010; Naysmith et al. 2010) and ${ }^{14} \mathrm{C}$ ages calculated using the background subtraction method (using an average background value of $\mathrm{Fm}=0.0034$, which was based on 6 targets prepared from our background bone sample). The bone background sample (Bos primigenis) derives from a placer mine site near Fairbanks, Alaska, and is at least Marine Isotope Stage 5 in age. Final ages are expressed as conventional ${ }^{14} \mathrm{C}$ ages BP (Stuiver and Polach 1977).

Subsamples of the collagen $(\sim 0.7 \mathrm{mg})$ were analyzed for ${ }^{13} \mathrm{C},{ }^{15} \mathrm{~N}$, and $\mathrm{C} / \mathrm{N}$ ratio using a ThermoFisher Delta V Advantage continuous-flow isotope ratio mass spectrometer interfaced to a Costech Instruments elemental combustion system. Again, $\delta^{13} \mathrm{C}$ values are reported with reference to VPDB and $\delta^{15} \mathrm{~N}$ values with respect to AIR.

\section{RESULTS AND DISCUSSION}

Tables 2 and 3 present the gelatin and carbon yields from the various samples. SUERC preparations generally had higher gelatin yields but lower percentage carbon. Table 4 illustrates the stable isotope data and Table 5 presents the ${ }^{14} \mathrm{C}$ results. 
Table 2 Analytical data for the samples analyzed at ORAU. Yield represents the weight of ultrafiltered gelatin in mg. Yield (\%) is the percent yield of extracted collagen as a function of the starting weight of the bone analyzed. $\mathrm{C}(\%)$ is the percentage carbon present in the combusted gelatin.

\begin{tabular}{llcccc}
\hline Sample reference & $\begin{array}{l}\text { OxA- } \\
\mathrm{nr}\end{array}$ & $\begin{array}{l}\text { Wt pretreated } \\
\text { bone }(\mathrm{mg})\end{array}$ & $\begin{array}{l}\text { Gelatin } \\
\text { yield }(\mathrm{mg})\end{array}$ & $\begin{array}{l}\text { Yield } \\
(\%)\end{array}$ & $\begin{array}{l}\mathrm{C} \\
(\%)\end{array}$ \\
\hline LQH12 & 21975 & 1120 & 77.7 & 6.9 & 44.6 \\
LQL4 & 21976 & 840 & 40.2 & 4.8 & 44.3 \\
LQL4 & 21977 & 1140 & 44.9 & 3.9 & 43.9 \\
LQL15 & 21978 & 1130 & 65.3 & 5.8 & 43.7 \\
369 & 21979 & 1030 & 112.4 & 10.9 & 42.5 \\
387 & 21980 & 598 & 59.5 & 9.9 & 43.2 \\
RDTW 01 <59> & 21981 & 1110 & 93.1 & 8.4 & 44.0 \\
Yarnton & 21982 & 890 & 79.2 & 8.9 & 42.6 \\
\hline
\end{tabular}

Table 3 Analytical data for the samples analyzed at SUERC. Gelatin yield represents the weight of gelatin in mg. Yield (\%) is the percent yield of extracted collagen as a function of the starting weight of the bone analyzed. C (\%) is the percentage carbon present in the combusted gelatin. NB: Duplicate analyses were carried out on single gelatin preparations.

\begin{tabular}{llllrl}
\hline Sample reference & $\begin{array}{l}\text { SUERC- } \\
\mathrm{nr}\end{array}$ & $\begin{array}{l}\text { Wt pretreated } \\
\text { bone }(\mathrm{mg})\end{array}$ & $\begin{array}{l}\text { Gelatin } \\
\text { yield }(\mathrm{mg})\end{array}$ & $\begin{array}{l}\text { Yield } \\
(\%)\end{array}$ & $\begin{array}{l}\text { C } \\
(\%)\end{array}$ \\
\hline LQH12 & $26632 / 3$ & 1969 & 200 & 10.2 & 40.3 \\
LQL4 & $26639 / 40$ & 3472 & 214 & 6.2 & 31.6 \\
LQL15 & $26634 / 5$ & 1756 & 213 & 12.1 & 43.5 \\
369 & $26641 / 2$ & 1838 & 250 & 13.6 & 41.8 \\
387 & $26643 / 4$ & 2773 & 272 & 9.8 & 44.0 \\
RDTW 01 <59> & $26645 / 9$ & 2020 & 214 & 10.6 & 41.0 \\
Yarnton & $26650 / 1$ & 2698 & 410 & 15.2 & 38.6 \\
\hline
\end{tabular}

Table 4 Stable isotope results and $\mathrm{C} / \mathrm{N}$ ratios for the samples analyzed. See text for measurement details. The standard errors on the stable isotope values are provided. $\mathrm{C} / \mathrm{N}$ is the atomic ratio of carbon to nitrogen and is acceptable if it ranges between 2.9 and 3.5 approximately. The differences between SUERC and ORAU are probably due to differences in the pretreatment applied, e.g. ultrafiltration, which has been shown to improve $\mathrm{CN}$ ratios (Bronk Ramsey et al. 2004).

\begin{tabular}{lllll}
\hline Sample reference & Laboratory $\mathrm{nr}$ & $\delta^{13} \mathrm{C}(\%)$ & $\delta^{15} \mathrm{~N}(\%)$ & $\mathrm{C} / \mathrm{N}$ ratio \\
\hline LQL4 & OxA-21976 & $22.1 \pm 0.2$ & $+8.2 \pm 0.3$ & 3.1 \\
LQL4 & OxA-21977 & $22.2 \pm 0.2$ & $+8.2 \pm 0.3$ & 3.1 \\
LQL4 & SUERC-26639 & $22.1 \pm 0.2$ & $+8.2 \pm 0.3$ & 3.4 \\
LQL4 & SUERC-26640 & $22.0 \pm 0.2$ & $+7.8 \pm 0.3$ & 3.5 \\
LQH12 & OxA-21975 & $21.9 \pm 0.2$ & $+7.0 \pm 0.3$ & 3.1 \\
LQH12 & SUERC-26632 & $21.8 \pm 0.2$ & $+7.2 \pm 0.3$ & 3.3 \\
LQH12 & SUERC-26633 & $21.9 \pm 0.2$ & $+7.4 \pm 0.3$ & 3.3 \\
LQL15 & OxA-21978 & $21.4 \pm 0.2$ & $+2.7 \pm 0.3$ & 3.1 \\
LQL15 & SUERC-26634 & $21.2 \pm 0.2$ & $+2.6 \pm 0.3$ & 3.3 \\
LQL15 & SUERC-26635 & $21.2 \pm 0.2$ & $+2.8 \pm 0.3$ & 3.3 \\
369 & OxA-21979 & $21.3 \pm 0.3$ & $+6.5 \pm 0.3$ & 3.1 \\
369 & SUERC-26641 & $21.0 \pm 0.2$ & $+8.6 \pm 0.3$ & 3.3 \\
369 & SUERC-26642 & $21.0 \pm 0.2$ & $+8.9 \pm 0.3$ & 3.3 \\
387 & OxA-21980 & $21.1 \pm 0.2$ & $+9.6 \pm 0.3$ & 3.1 \\
387 & SUERC-26643 & $20.8 \pm 0.2$ & $+10.2 \pm 0.3$ & 3.3
\end{tabular}


Table 4 Stable isotope results and $\mathrm{C} / \mathrm{N}$ ratios for the samples analyzed. See text for measurement details. The standard errors on the stable isotope values are provided. $\mathrm{C} / \mathrm{N}$ is the atomic ratio of carbon to nitrogen and is acceptable if it ranges between 2.9 and 3.5 approximately. The differences between SUERC and ORAU are probably due to differences in the pretreatment applied, e.g. ultrafiltration, which has been shown to improve $\mathrm{CN}$ ratios (Bronk Ramsey et al. 2004). (Continued)

\begin{tabular}{lllll}
\hline Sample reference & Laboratory $\mathrm{nr}$ & $\delta^{13} \mathrm{C}(\%)$ & $\delta^{15} \mathrm{~N}(\%)$ & $\mathrm{C} / \mathrm{N}$ ratio \\
\hline 387 & SUERC-26644 & $20.8 \pm 0.2$ & $+10.2 \pm 0.3$ & 3.3 \\
Yarnton & OxA-21982 & $21.1 \pm 0.2$ & $+10.0 \pm 0.3$ & 3.1 \\
Yarnton & SUERC-26650 & $21.2 \pm 0.2$ & $+10.7 \pm 0.3$ & 3.3 \\
Yarnton & SUERC-26651 & $21.2 \pm 0.2$ & $+10.9 \pm 0.3$ & 3.3 \\
RDTW 01 <59> & OxA-21981 & $20.8 \pm 0.2$ & $+8.1 \pm 0.3$ & 3.1 \\
RDTW 01 <59> & SUERC-26645 & $20.9 \pm 0.2$ & $+8.8 \pm 0.3$ & 3.3 \\
RDTW 01 <59> & SUERC-26649 & $20.9 \pm 0.2$ & $+8.7 \pm 0.3$ & 3.3 \\
\hline
\end{tabular}

Table 5 Radiocarbon results from the Oxford and SUERC laboratories.

\begin{tabular}{llll}
\hline Sample reference & Lab nr & Net F value $\pm 1 \sigma$ & ${ }^{14} \mathrm{C}$ age $^{\mathrm{a}} \mathrm{BP} \pm 1 \sigma$ \\
\hline LQL4 & SUERC-26639 & $-0.0003 \pm 0.0007$ & $>49,500$ \\
LQL4 & SUERC-26640 & $-0.0005 \pm 0.0007$ & $>49,500$ \\
LQL4 & OxA-21976 & $0.00117 \pm 0.00097$ & $>46,400$ \\
LQL4 & OxA-21977 & $0.00016 \pm 0.00096$ & $>49,600$ \\
LQH12 & SUERC-26632 & $0.0008 \pm 0.0007$ & $>49,500$ \\
LQH12 & SUERC-26633 & $0.0003 \pm 0.0007$ & $>49,500$ \\
LQH12 & OxA-21975 & $0.00202 \pm 0.00098$ & $49,900+5270 /-3240$ \\
LQL15 & SUERC-26634 & $0.0009 \pm 0.0007$ & $>49,500$ \\
LQL15 & SUERC-26635 & $0.0010 \pm 0.0007$ & $>49,500$ \\
LQL15 & OxA-21978 & $0.00163 \pm 0.00096$ & $>45,300$ \\
369 & SUERC-26641 & $-0.0010 \pm 0.0007$ & $>49,500$ \\
369 & SUERC-26642 & $-0.0007 \pm 0.0007$ & $>49,500$ \\
369 & OxA-21979 & $0.00038 \pm 0.00093$ & $>49,000$ \\
387 & SUERC-26643 & $0.0031 \pm 0.0007$ & $46,400+2060 /-1630$ \\
387 & SUERC-26644 & $0.0035 \pm 0.0007$ & $45,400+1820 /-1440$ \\
387 & OxA-21980 & $0.00382 \pm 0.00097$ & $44,700+2380 /-1790$ \\
Yarnton & SUERC-26650 & $0.0002 \pm 0.0007$ & $>49,500$ \\
Yarnton & SUERC-26651 & $0.0003 \pm 0.0007$ & $>49,500$ \\
Yarnton & OxA-21982 & $0.00194 \pm 0.00098$ & $>44,600$ \\
RDTW 01 $<59>$ & SUERC-26645 & $0.0011 \pm 0.0007$ & $>49,500$ \\
RDTW 01 $<59>$ & SUERC-26649 & $0.0005 \pm 0.0007$ & $>49,500$ \\
RDTW 01 <59> & OxA-21981 & $0.00194 \pm 0.00098$ & $>44,500$ \\
\hline
\end{tabular}

a SUERC minimum age is based on $3 \times$ error on background value.

Despite their considerable ages, the bones were all surprisingly well preserved. We found collagen yields of $\sim 4-11 \%$ by weight (Oxford) and $6-15 \%$ by weight (SUERC) (Tables 2,3 ). The SUERC higher yields are likely the result of undertaking neither a $\mathrm{NaOH}$ wash nor ultrafiltration. Other analytical parameters, such as the value for $\% \mathrm{C}$ in combustion, were entirely consistent with typical values (van Klinken 1999). The lower carbon yields in the samples prepared at SUERC are as yet not understood. Based on $\mathrm{C} / \mathrm{N}$ atomic ratios, recovered collagen samples also appear to be in a good state of preservation as they are all within the 2.9-3.5 approximate range (Table 4) that is widely accepted in ${ }^{14} \mathrm{C}$ and stable isotope studies (Ambrose 1990). SUERC C/N ratios are consistently higher by about 0.2 . We have no clear explanation for this, although it is likely to relate to the dif- 
ferences in pretreatment and in particular to the use of ultrafiltration at Oxford. All $\delta^{13} \mathrm{C}$ values for mammoth and bison are typical of these species (Iacumin et al. 2000).

We obtained "greater than" ages for the vast majority of the samples, which is consistent with the age attribution of the corpus of bones. The exception was for bone 387, the bison from Oxey Mead. Consistent results were obtained at both facilities for this sample. The excellent preservation state of the bone, the consistent results obtained for both analytical parameters and ${ }^{14} \mathrm{C}$ measurements, and the fact that the results are securely finite, suggests to us at least the possibility that this bone is not actually of the age ascribed. It may be that it is intrusive, and dates from a later (MIS 3 ) period. The alternative is that the age is an underestimate.

One important recurring problem in obtaining standards for ${ }^{14} \mathrm{C}$ intercomparison has been the issue of sample homogeneity (Scott et al. 2004). The advantage of the samples we have dated here is that each is a single entity, i.e. a single bone. Therefore, the principal issue that concerns us is contamination. The evidence presented in this paper suggests that contamination is unlikely to be a significant influence, for which there are 2 reasons. First, contamination is often linked closely with diagenetic alteration of the bone, with bone yielding $<1 \% \mathrm{wt}$ collagen often producing ages at odds with those expected. Collagen becomes increasingly difficult to characterize with confidence on a routine basis when yields fall to this level; therefore, it is usually the case that ${ }^{14} \mathrm{C}$ laboratories fail these types of sample. The reverse is the case here where the bones are uniformly well preserved. Second, the application of 2 related, though importantly different, pretreatment protocols suggests minimal contamination. The Oxford method differs from that applied at SUERC in that a $\mathrm{NaOH}$ wash was used (to attempt to solubilize humates) and an ultrafiltration protocol was applied (Brown et al. 1988; Bronk Ramsey et al. 2004; Higham et al. 2006). The consistent "greater than" ages, and close agreement between ages for the same material in the 2 facilities suggests limited contamination, unless the contamination is removed equally by the 2 different protocols. This appears unlikely based on experience. For some of the bone samples, the limit of detection varies between the 2 laboratories and this is not necessarily due to sample preparation. This difference in limit of detection can be due to a number of reasons: 1. Background in a single AMS is not constant and will vary through time. Consequently, the limit of detection will vary; 2 . There may be small differences in background between the 2 AMS instruments; 3 . Limit of detection calculations can vary between laboratories.

\section{CONCLUSIONS}

Seven bone samples thought to be suitable as standards for quantification of chemistry background for ${ }^{14} \mathrm{C}$ dating of bone have been collected and analyzed. Preliminary ${ }^{14} \mathrm{C}$ dating suggests the ages obtained for 6 are consistent with the samples being greater than the ${ }^{14} \mathrm{C}$ age limit and therefore consistent with their independent age of MIS 5-7. There is 1 exception and further work is required to assess whether this is due to a problem in the ${ }^{14} \mathrm{C}$ dating or to the bone being intrusive and of a younger age than expected. At present, we favor the latter explanation because the ages obtained in the 2 laboratories are in good agreement, and the pretreatment yields are high. The 6 "greater than" age samples will be made available to ${ }^{14} \mathrm{C}$ laboratories to be used as background standards.

\section{ACKNOWLEDGMENTS}

We thank Katharine Scott for providing the bone samples, Andrew Currant (The Natural History Museum, London) for faunal identifications, and Prof Johannes van der Plicht and John Southon for their requests for this type of material, which stimulated us to find some. Finally, we thank all laboratory staff for their assistance. 


\section{REFERENCES}

Ambrose SH. 1990. Preparation and characterization of bone and tooth collagen for isotopic analysis. Journal of Archaeological Science 17(4):431-51.

Bayliss A. 2009 Rolling out revolution: using radiocarbon dating in archaeology. Radiocarbon 51(1):12347.

Bayliss A, Bronk Ramsey C. 2004. Pragmatic Bayesians: a decade of integrating radiocarbon dates into chronological models. In: Buck CE, Millard AR, editors. Tools for Constructing Chronologies: Tools for Crossing Disciplinary Boundaries. London: Springer Verlag. p 25-41.

Bayliss A, Whittle A, editors. 2007. Histories of the dead: building chronologies for five southern British long barrows. Cambridge Archaeological Journal 17 (Supplement 1).

Bayliss A, Bronk Ramsey C, van der Plicht J, Whittle A. 2007. Bradshaw and Bayes: towards a timetable for the Neolithic. Cambridge Archaeological Journal 17(Supplement 1):1-28.

Brock F, Bronk Ramsey C, Higham T. 2007. Quality assurance of ultrafiltered bone dating. Radiocarbon 49(2):187-92.

Brock F, Higham T, Ditchfield P, Bronk Ramsey C. 2010. Current pretreatment methods for AMS radiocarbon dating at the Oxford Radiocarbon Accelerator Unit (ORAU). Radiocarbon 52(1):103-12.

Bronk Ramsey C, Higham TFG, Bowles A, Hedges R. 2004. Improvements to the pretreatment of bone at Oxford. Radiocarbon 46(1):155-63.

Brown TA, Nelson DE, Vogel JS, Southon JR. 1988. Improved collagen extraction by modified Longin method. Radiocarbon 30(2):171-7.

Dee M, Bronk Ramsey C. 2000. Refinement of graphite target production at ORAU. Nuclear Instruments and Methods in Physics Research B 172(1-4):449-53.

D'Elia M, Gianfrate G, Quarta G, Giotta L, Giancane G, Calcagnile L. 2007. Evaluation of possible contamination sources in the ${ }^{14} \mathrm{C}$ analysis of bone samples by FTIR spectroscopy. Radiocarbon 49(2):201-10.

Eeles RMG. 2009. Summary of research undertaken at Nyett Field (Thrupp) in the parish of Radley, Oxfordshire [WWW document]. URL: http://www.radleyvillage.org.uk/ourvillage/natural_history/documents/ THRUPPREPORTRMGEelesNov2009.pdf.

Freeman SPHT, Cook GT, Dougans AB, Naysmith P, Wilcken KM, Xu S. 2010. Improved SSAMS performance. Nuclear Instruments and Methods B 268(7-8):715-7.

Hedges REM, van Klinken GJ. 1992. A review of current approaches in the pretreatment of bone for radiocarbon dating by AMS. Radiocarbon 34(3):279-91.

Higham TFG, Jacobi RM, Bronk Ramsey C. 2006 AMS radiocarbon dating of ancient bone using ultrafiltration. Radiocarbon 48(2): 179-95.

Hüls CM, Grootes PM, Nadeau M-J. 2007. How clean is ultrafiltration cleaning of bone collagen. Radiocarbon 49(2):193-200.

Hüls CM, Grootes PM, Nadeau M-J. 2009. Ultrafiltration: boon or bane? Radiocarbon 51(2):613-25.

Iacumin P, Nikolaev V, Ramigni M. 2000. C and N stable isotope measurements on Eurasian fossil mammals, 40,000 to 10,000 years BP: herbivore physiologies and palaeoenvironmental reconstruction. Palaeogeography, Palaeoclimatology, Palaeoecology 163(1-2):33-47.

Jacobi RM, Higham TFG, Bronk Ramsey C. 2006. AMS radiocarbon dating of Middle and Upper Palaeolithic bone in the British Isles: improved reliability using ultrafiltration. Journal of Quaternary Science 21(5): 557-73.

Lewis SG, Maddy D, Buckingham C, Coope GR, Field MH, Keen DH, Pike AWG, Roe DA, Scaife RG, Scott K. 2006. Pleistocene fluvial sediments, palaeontology and archaeology of the upper River Thames at Latton, Wiltshire, England. Journal of Quaternary Science 21(2):181-205.

Longin R. 1971. New method of collagen extraction for radiocarbon dating. Nature 230(5291):241-2.

McCullagh JSO, Marom A, Hedges REM. 2010. Radiocarbon dating of individual amino acids from archaeological bone collagen. Radiocarbon 53(2):620-34.

Naysmith P, Cook GT, Freeman SPHT, Scott EM, Anderson R, Xu S, Dunbar E, Muir GKP, Dougans A, Wilcken K, Schnabel C, Russell N, Ascough PL, Maden C. $2010 .{ }^{14} \mathrm{C}$ AMS at SUERC: improving QA data with the $5 \mathrm{MV}$ tandem and $250 \mathrm{kV}$ SSAMS. Radiocarbon 52(2-3):263-71.

Nelson DE. 1991. A new method for carbon isotopic analysis of protein. Science 251(4993):552-4.

Scott EM, Boaretto E, Bryant C, Cook GT, Gulliksen S, Harkness DD, Heinemeier J, McGee E, Naysmith P, Possnert G, van der Plicht H, Van Strydonck M. 2004. Future needs and requirements for AMS ${ }^{14} \mathrm{C}$ standards and reference materials. Nuclear Instruments and Methods in Physics Research B 223-224:382-7.

Scott K, Buckingham CM. 2001. Preliminary report on the excavation of late Middle Pleistocene deposits at Latton, near Cirencester, Gloucestershire. Quaternary Newsletter 94:24-9.

Slota Jr PJ, Jull AJT, Linick TW, Toolin LJ. 1987. Preparation of small samples for ${ }^{14} \mathrm{C}$ accelerator targets by catalytic reduction of CO. Radiocarbon 29(2): 303-6.

Stafford TW, Hare PE, Currie L, Jull AJT, Donahue DJ. 1991. Accelerator radiocarbon dating at the molecular level. Journal of Archaeological Science 18(1):35-72.

Stuiver M, Polach HA. 1977. Discussion: reporting of ${ }^{14} \mathrm{C}$ data. Radiocarbon 19(3):355-63.

Tisnérat-Laborde N, Valladas H, Kaltnecker E, Arnold M. 2003. AMS radiocarbon dating of bones at LSCE. Radiocarbon 45(3):409-19. 
Vandeputte K, Moens L, Dams R. 1996. Improved sealed-tube combustion of organic samples to $\mathrm{CO}_{2}$ for stable carbon isotope analysis, radiocarbon dating and percent carbon determinations. Analytical Letters 29(15):2761-73.

van Klinken GJ. 1999. Bone collagen quality indicators for palaeodietary and radiocarbon measurements. Journal of Archaeological Science 26(6):687-95.
Wood RE, Bronk Ramsey C, Higham TFG. 2010. Refining the ultrafiltration bone pretreatment background for radiocarbon dating at ORAU. Radiocarbon 52(23):600-11.

Yuan S, Wu X, Liu K, Guo Z, Cheng X, Pan Y, Wang J. 2007. Removal of contaminants from oracle bones during sample pretreatment. Radiocarbon 49(2):2116. 